\title{
The Role of Health and Medical Profession in Indonesia
}

\section{Adi Heru Sutomo*}

Department of Family Medicine, Gadjah Mada University School of Health \& Medicine, Jogjakarta, Java, Indonesia

*Corresponding author: Adi Heru Sutomo, Department of Family Medicine, Gadjah Mada University School of Health \& Medicine, Jogjakarta, Java, Indonesia, Tel: 0274-566295; E-mail: adiheruhusodo@gmail.com

Rec date: Jan 23, 2014 Acc date: June 10, 2015 Pub date: June 15, 2015

Copyright: ( 2015 Sutomo $\mathrm{AH}$. This is an open-access article distributed under the terms of the Creative Commons Attribution License, which permits unrestricted use, distribution, and reproduction in any medium, provided the original author and source are credited.

\begin{abstract}
Introduction: In the context of public health, there are many problems in Indonesia, for instance the variation of many islands like Java, Sumatra, Kalimantan, Papua, Bali, Nusa Tenggara etc. contains huge population, with various tribes requiring income, public health services and making of public health policy.
\end{abstract}

Thus in relation with above mentioned conditions, the application of public health program should be considered with at most importance due to its variations in the role of health and medical in reference with various occupations.

Method: This paper is made based on library studies that are compiled from different data which is hopefully used to construct the right of scientific writing in the context of public health sciences in relation to the General Medicine.

Result and Discussion: Quite clear that there are many public health aspects that need to be taken into policy in relation to clinical aspects, health financing aspects, health economic aspects, and in general to explain the understanding of primary health services and secondary health services and their functions. There is a need to develop the real and perfect program for general physicians who can be used to support the primary health centre. It is important to know that, a common Indonesian not only requires health financing program, but also the right medical education program, the right family medicine program, the right primary health care, the right population health care etc. should also be designed.

Conclusion: There is a need to manage the role of health and medical profession in Indonesia in a specific way, where it works together in a harmony related with different other occupations such as instance sociologists, psychologists, lawyers, technical experts etc.

Keywords: Population; Public health; Indonesia; Public health policy; Medical and nursing services

\section{Introduction}

Indonesia is one of the ASEAN Countries that close to Malaysia, Singapore, Philippine, Thailand and Australia where the distance between these countries is very less, it is very important that quality of health services and medical services in Indonesia should be better than other countries. AFTA (Asean Free Trade Agreement) and APEC (Asia Pacific Economic Cooperation) joining ASEAN by 2016-2020, will be having challenging time with all ASEAN countries facing directly, with issues as including the health services and medical services. In this scenario, to understand the importance and context of public health, this paper going to concentrate in the role of health and medical profession in Indonesia.

\section{Method}

In 1920, Prof. Dr. Charles Edward A Winslow from Yale University, United States of America, founder of the classical Public Health (Hanlon, 1955) made a statement that "Public Health is the science and art of preventing disease, prolonging life, promoting health and efficiency, through organized community effort for the sanitation of environment, the control of communicable infections, the education of the individual in personal hygiene, the organization of medical and nursing services for the early diagnosis and preventive treatment of disease, and the development of the social machinery to insure everyone a standard of living adequate for the maintenance of health" $[1,2]$. So organizing these benefits leads to enable every citizen realizing his birth right of health and longevity.

\section{In relation to the above mentioned, then Hanlon (1955) emphasized his statement that the dimensions of public health were in 4 (four) fields, including:}

- Activities in the community related to food, water and milk supervisions, insect control, and air pollution control.

- Prevention activities for diseases and premature death, example, communicable disease control, food deficiency, drug addictivity, treatment for allergy and its sources in the community, mental diseases and atittude related to diseases, occupational health, carcinoma, cardiovasculer diseases, situation related to the risks as results of maternity, growth and development, the risks of genetic factors, accidents in the home, at the public and in industry, health rehabilitation to the victims of accidents and patients, and patients of dental caries. 
- Medical activities such as medical office organization, medical staffs education, distribution of medical staffs and medical facilities

- Researches activities like Public Health Administration researches, liver infection outbreak etc.

\section{According to Hanlon, the preventive medicine consist of (Hanlon, 1955)}

- Biological Prevention, due to dificiencies, and the like.

- Prevention for the results of chronical diseases.

- Prevention for the effects of diseases that can not be prevented or can not be cured.

Detels and Breslow (Detels et al.) in the context of the modern public health wrote that [3]:

"Public health is the process of mobilizing local, state, national and international resources to ensure the conditions in which people can be healthy. It means that public health instruments and its operational are very different from the traditional or the classical public health."

The view of the Modern public health is already mentioned in the Block V of public health lectures of Gadjah Mada University School of Health \& Medicine as below, writtern as [4]:

"A community and society is not a group or groups of individuals. Community should not be interpreted as the local community, but also seen within national and international context, for example: global aids movement...”

\section{John M. Last (Last, 1998; Scutchfield and Keck, 1997) from University of Ottawa-Canada wrote that:}

Public health is one of the efforts organized by society to protect, promote and restore people health. It is a combination of science, practical skills and values (or beliefs) that are directed towards the maintenance and improvement of the health of all the people through collective or social actions.

The programs, services and institutions involved emphasize the prevention of disease and the health needs of the population as a whole. Public health activities change with changing technology and values, but the goals remain the same - to reduce the amount of disease, premature death, and disease produced discomfort and disability in the population. Public health is thus a social institution, a discipline and a practice.

So the Modern Public Health as mentioned above is a quite flexible and most important is the goals: To reduce the diseased conditions, premature death causes discomfort and disability in the population.

John M Last also wrote that Preventive Medicine is identical to Community Medicine, that is "Preventive Medicine or Community Medicine is a specialized field of medical practice focusing on the health of defined populations in order to promote and maintain health and wellbeing and prevent disease, disability and premature death".

It explains that preventive medicine is same as community medicine and is a application of medical practice in the community, focusing promotion and maintaining the health, ultimately preventing disease and disability [5].

\section{In 2001, it was a concept of the new public health which emphasized that the new public health should have:}

- Giving treatment for diseases, which are related to environmental issues, policies, economic and health services marketing.

- Public Health can run independently, which means Public Health can run based on self funding and self management, and not always dominated by governments [6].

Below is the description of public health situation in ASEAN Countries including Indonesia around 2010 (Figure 1):

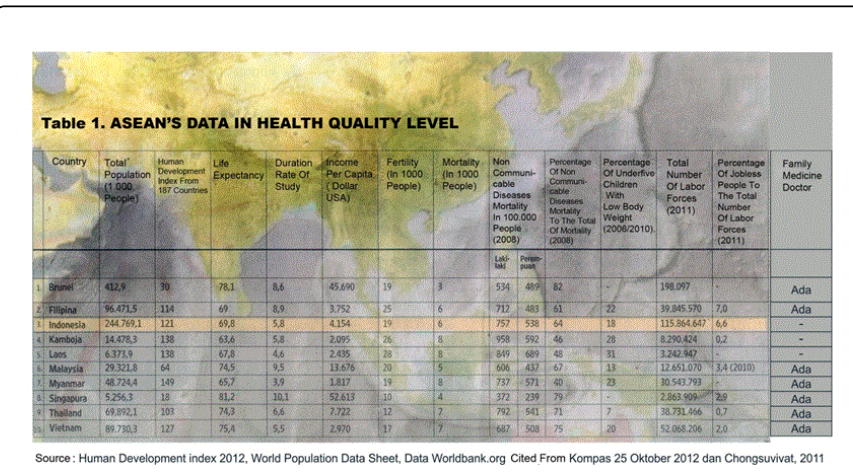

Figure 1: Showing that there were many variations of ASEAN'S DATA which giving information about life expectancy, income per-capita, total number of population, the availability of Family Doctor, and so on, where hopefully by looking at the above table then there will be the best decision on Public Health Policy can be made.

By looking at the Human Development Index, it is quite clear that Singapore, Brunai and Malaysia are the 3 (three) best countries in ASEAN countries in maintenance of public health system. In the context of the Life Expectancy, the best number is with countries such as Singapore, Brunai, Vietnam (75.4 years), Malaysia (74.5 years) and Thailand (74.3 years). In the context of the Duration Rate of Study, Singapore is the best (10.1 years), Malaysia stands second (9.5 years), Philipines third (8.9 years) and Brunai is fourth (8.6 years).

By looking at Income Per Capita (Dollar USA), Singapore (52,613 US Dollar) has major rate along with Brunai (45,690 US Dollar), Malaysia (13,676 US Dollar), Thailand (7,722 US Dollar) and Indonesia $(4,154$ US Dollar) in next three places respectively. Indonesia is almost the same as the Philipine which is its income percapita is 3,752 US $\$$.

When it comes to fertility rate (in 1000 People), the best is Singapore, where 10 results are fertile among 1000 people, and the second is Thailand with 12 per 1000 people, and the third is Vietnam with 17 among 1000 people, while Indonesia is 19 fertility among 1000 people. In this case Indonesia has best rate among other countries.

In case of mortality rate (in 1000 People), the lowest mortality number is recorded in Brunai ( 3 mortality among 1000 people), the second is Singapore (4 mortality among 1000 people), and the third is Malaysia (5 mortality among 1000 people), while Indonesia is 6 mortality among 1000 people, and that number is the same as the Philipine 6 mortality among 1000 people.

Percentage of underfive children with low body weight (2006/2010), the lowest number or the best is Thailand with 7 Underfive Children 
with low body weight, and the second is Malaysia with 13 Underfive Children with low body weight, and Indonesia is the third with 18 Underfive Children with low body weight, while both Singapore and Brunai do not have any data for the Underfive Children with low body weight.

Total number of labor forces (2011), Indonesia is the largest with total number of labor forces of $115,864,647$ people, and the second is Vietnam with the total number of labor forces of 52,068,206 people and the third is the Philipine with total number of $39,845,570$ people, and the fourth is Thailand with total number of labor forces of $38,731,466$ people.

Percentage of jobless people to the total number of labor forces (2011), the highest number of jobless people in ASEAN is the Philipine with total number of $7 \%$, and the second is Indonesia with total number of $6.6 \%$ almost the same as the Philipine, and the third is
Malaysia with total number of $3.4 \%$, and then the fourth is Singapore with total number of $2.9 \%$ and Vietnam with total number of $2.0 \%$, while Brunai, Laos and Myanmar do not have any data.

All ASEAN countries also have family medicine education program and they also implemented the family medicine services in their own countries, except Indonesia, Laos and Cambodia.

At the moment the Indonesian Government is running the Indonesian's Preparedness on the way to BPJS (Badan Penyelenggara Jaminan Social or the National Indonesian Health Insurance) which was started on 1st January 2014, which was basically based on Administrative \& Health Financing programme.

It means that there will be very small attentions to the development of medical skills that related to the development of public health (Table 1).

\begin{tabular}{|l|l|l|l|}
\hline $\begin{array}{l}\text { Total Number } \\
\text { Of GP in PHC }\end{array}$ & $\begin{array}{l}\text { Total Number } \\
\text { of PHC }\end{array}$ & $\begin{array}{l}\text { Total Number } \\
\text { of Members }\end{array}$ & $\begin{array}{l}\text { Rate of Members } \\
\text { in each PHC }\end{array}$ \\
\hline No GP & 877 & $8,298,444$ & 604 \\
\hline 1 GP & 3,212 & $30,142,348$ & 938 \\
\hline $2-3$ GP & 3,716 & $38,179,278$ & 107 \\
\hline $4-5$ GP & 834 & $7,913,104$ & 992 \\
\hline$>5$ GP & 257 & $2,466,853$ & 1,007 \\
\hline Total & 8,699 & $84,000,027$ & 696 \\
\hline
\end{tabular}

Table 1: Availability of Indonesian Doctor \& Membership of JKN (National Health Insurance) in Primary Health Centre in Indonesia [7].

The above Table 1 shows that many Primary Health Centre or Puskesmas (Pusat Kesehatan Masyarakat) in Indonesia do not have Doctor or General Physicians (GP), even though the number of patients are high (604 members) in number. In Indonesia, so far whether a person is a patient or a member of health insurance, they come to Primary Health Centre, but many don't understand the membership of health insurance.

In general, in Indonesia the people mostly visit hospitals or medical specialists, rather than Puskesmas (Primary Health Centre/PHC) or
General Physicians (GP), therefore PHC or GP tend to be used when the people want to refer to hospital or medical specialist.

Based on the above writings, it could be understood how well community knows the GP in doing their jobs as a doctor, if not, maybe there is something wrong with the health administration, medical record system, the sanitation, the nutrition, the water, the people habit in their life etc. (Table 2).

\begin{tabular}{|l|l|l|l|}
\hline $\begin{array}{l}\text { Secondary Health } \\
\text { Services (Hospital) }\end{array}$ & $\begin{array}{l}\text { Total Number } \\
\text { of Hospital }\end{array}$ & $\begin{array}{l}\text { Total Number of hospital Cooperate with } \\
\text { BPJS started From 1-1-2014 }\end{array}$ & $\begin{array}{l}\text { Potential Health Facilities Which May Be } \\
\text { Cooperate With BPJS In 2014-2019 }\end{array}$ \\
\hline Government Hospital & 589 & 533 & 56 \\
\hline Non-Government Hospital & 961 & 919 & 42 \\
\hline Private and Psychiatric Hospital & 505 & 109 & 396 \\
\hline Military Hospital & 114 & 104 & 10 \\
\hline Policeman Hospital & 45 & 45 & 0 \\
\hline Total & 2,214 & 1,710 & 504 \\
\hline
\end{tabular}

Table 2: Secondary health services or Hospital in JKN (National Health Insurance), 2014 [7].

By looking at the above Table 2, we could say not all military hospitals can be joined in BPJS 2014. It is same in the case of Private
Hospitals and Psychiatric Hospitals which can be cooperated with BPJS by 1 st January, 2014 is only $20 \%$. It also happened with 
Government Hospital and Non Government Hospital. Why do the participation number of hospital (Secondary Health Services) and doctor or Puskesmas (Primary Health Services) relativelly low? Of course it must be something wrong with that program.

Table 3 is showing different data from Table 1 which says: Firstly, the total number of PHC is 8,699 , on the other hand, in November, 2013, where as total number of PHC was 9,599. Secondly, Table 1 says that total number of PHC which do not have any doctors is 877 Primary Health Centres, on the other hand, data of November, 2013, wrote that total number of PHC which do not have any doctor were 1,327 Primary Health Centre. The miss-classification that happened in the above Tables 1 and 3 may be due to the low coordination among the sources.

\begin{tabular}{|l|l|}
\hline Number of PHC & 9,599 \\
\hline Number of PHC with no doctor & 1,327 \\
\hline The need to have doctors & 3,706 \\
\hline
\end{tabular}

Table 3: Availability of doctor and hospital bed for BPJS in November 2013 [8].

Table 3 also showing the need to have 3,706 doctors. Based on this report actually, it can be understood clearly that recruiting medical sources is a difficult problem, because of some reasons, though other beneficiaries are also included, such as, the kind of jobs, the salary, transportation and medical skills. Table 4 showing that the availability of governmental hospital beds were higher than the non governmental hospital beds, and there is a need to have some more beds with a total number of 121,000 . It means that BPJS should plan whether adding some more hospital beds or building some more hospitals will fulfil its needs.

\begin{tabular}{|l|l|}
\hline Hospital & Total bed \\
\hline Government hospital & 115,000 \\
\hline Non Government hospital & 83,600 \\
\hline The need to have some more bed & 121,000 \\
\hline
\end{tabular}

Table 4: Availability of hospital bed for BPJS in November 2013 [8].

In short, by looking at all the ASEAN's data of health indicators as what mentioned above, then it can be concluded that:

- In general, the public health level of Indonesia is lower than the developed countries in ASEAN, but relatively a slight better than the other ASEAN countries.

- Until the year 2012, the Indonesian Life Expectancy was 69.8 years the same as the Philipine, but lower than Singapore, Malaysia, Brunai, Thailand and Vietnam.

- Until the year 2012, the Total Fertility Rate was 19 per 1000 population and that was the same as Brunai and Myanmar, but that number was much higher than Singapore (10 fertility in 1000 population) and Thailand ( 12 fertility in 1000 population).

- Indonesia was the most populated country in ASEAN. The Indonesian Mortality Rate was 6 in 1000 people, and it was the same as the Philipine, and higher than Brunai (3 in 1000 people), Singapore (4 in 1000 people) and Malaysia (5 in 1000 people).

- Mortality Rate as a result of non communicable diseases in 100,000 people was 757 for man, and 538 for woman. It means that other than infection diseases in Indonesia, there were also non infection diseases.

- In Indonesia, percentage of Underfive Children with Low Body Weight was $18 \%$, and that was lower or smaller than the Philipine (22\%), Cambodia (28\%), Laos (31\%), Myanmar (23\%) and Vietnam (20\%), but this number was far from Thailand (7\%) and Malaysia (13\%)

- Indonesia, Cambodia and Laos were the 3 (three) countries in ASEAN which have not implemented Family Medicine program in their countries yet.

Though different concepts, such as, family medicine, health insurance, managed care or health financing are included and implemented, it is difficult to know, the level of public health in Indonesia. Because, not only these reasons, many other issue also to be considered, like, quality of health and medical resources, including their skills and attitude, the environment where they are living, the facilities they need to work, training and education, research etc. $[9,10]$.

\section{Conclusion}

The role of health and medical professions in Indonesia need to be considered perfectly. Health development cannot be seen from health financing and administration only, and therefore there is a need to take a look many other sectors, and human resources including the quality of General Physicians, nurse, midwife, Public Health workers, medical instruments, and many more.

\section{References}

1. Scutchfield F Douglas, Keck C William (1997) Principles of public health practice, Delmar Publisher Inc., Columbia, New York, USA.

2. Hanlon, John J (1955) Principles of public health administration, School of Public Health, University of Michigan, Second Edition, The CV. Mosby Company, St.Louis, USA

3. Roger D, Lester B (1997) Current scope \& concerns in public health, in Detels, Roger; Holland, Walter W; McEwen, James and Omenn, Gilbert S (Eds) Oxford Textbook of Public Health, The Scope of Public Health, Oxford University Press, Oxford 1: 3 .

4. Fatwa Sari Tetra D, Trisnantoro L, Kusnanto H, Mubasysyir (2004) Block $\mathrm{v}$ book public \& entrepreneurship, Second Edition, in Soewadi, Ahmad,Riris Andono \& Kushadiwijaya, Haripurnomo (eds), Gadjah Mada University School of Medicine, Yogyakarta.

5. Last, John M (1998) Public health and human ecology, Second Edition, Appleton \& Lange, Prentice Hall International (UK), and London.

6. Ncayayina (2001) The new public health, World Health Organization, Division of Public Health, Geneve.

7. Resolusi G (2014) Menjamin Kesehatan Rakyat, Gatra Magazine, Jakarta

8. Anton W (2013) Program Jaminan Kesehatan Nasional Pasien Bisa Tak Tertangani, Tempo, 29 November 2013. Jakarta.

9. Chongsuvivatwong (2011) Health and healthcare system in south east asia : diversity and transition, The Lancet, United Kingdom 377: 429-437.

10. Kompas (2013) Pertumbuhan ekonomi kualitas manusia jadi taruhan, Harian Umum Kompas, 25 October 2013, Jakarta. 